\title{
Metazoan Parasites of the Common Carp (Cyprinus carpio L., 1758) from Tahtalı Dam Lake (İzmir)
}

Tahtalı Baraj Gölü’ndeki (İzmir) Sazan’ın ( Cyprinus carpio L. , 1758) Metazoon Parazitleri

\author{
Hatice Karakişi, Seda Demir \\ Ege Üniversitesi Fen Fakültesi, Biyoloji Bölümü Zooloji Anabilim Dalı, İzmir, Türkiye
}

\section{ABSTRACT}

Objective: The aim of this study was identification of the parasites of the common carp from Tahtalı Dam Lake.

Methods: The fish were transported live to the laboratory. They were investigated for ectoparasites and endoparasites. The parasite specimens were fixed and identified.

Results: During the study, 47 common carp were caught monthly and 3 species of metazoan parasites were found: Dactylogyrus extensus (Monogenea), Contracaecum sp. larvae (Nematoda) and Lernaea cyprinacea (Crustacea).

Conclusion: The parasite species were new records for Tahtalı Dam Lake. Contracaecum sp. larvae were recorded for the first time from Cyprinus carpio in Turkey. (Turkiye Parazitol Derg 2012; 36: 174-7)

Key Words: Common carp (Cyprinus carpio), ectoparasite, endoparasite, Tahtalı Dam Lake

Received: 14.02 .2012

Accepted: 04.06 .2012

\section{ÖZET}

Amaç: Bu çalı̧̧manın amacı Tahtalı Baraj Gölü'nde yaşayan sazanın parazitlerini teşhis etmektir.

Yöntemler: Balıklar canlı olarak laboratuvara getirildi. Ektoparazit ve endoparazitler yönünden incelendi. Parazitler fikse edildi ve teşhis edildi.

Bulgular: Çalışma boyunca 47 sazan aylık olarak yakalanmıştır ve 3 metazoon parazit türü bulunmuştur: Dactylogyrus extensus (Monogenea), Contracaecum sp. larva (Nematoda) ve Lernaea cyprinacea (Crustacea).

Sonuç: Parazit türleri Tahtalı Baraj Gölü için yeni kayıtlardır. Contracaecum sp. larvası Türkiye'deki sazanlarda ilk defa kaydedilmiştir. (Turkiye Parazitol Derg 2012; 36: 174-7)

Anahtar Sözcükler: Sazan (Cyprinus carpio), ektoparazit, endoparazit, Tahtalı Baraj Gölü

Geliş Tarihi: 14.02.2012

Kabul Tarihi: 04.06.2012

\section{INTRODUCTION}

The cyprinid fish species common carp (Cyprinus carpio L., 1758) is a widespread freshwater fish. They are a warm water species. They can tolerate a variety of environmental conditions and habitat types, so they can invade a large geographical area. Its original home is Southeast Asia, but later it spread to Europe (except Siberian), Britain and even
America. They are found in many lakes (except very cold high-mountain lakes), ponds and dams of Anatolia (1).

Investigations on the parasites of Cyprinus carpio in Turkey was performed by Aydoğdu et al. (2), Kır et al. (3), Öztürk (4), Uzunay et al. (5), Kır et al. (6), Tekin-Özan et al. (7). In these studies, several parasites were recorded: Dactylogyrus minutus, Bothriocephalus acheilognathi, Caryophyllaeus

Address for Correspondence / Yazışma Adresi: Dr. Hatice Karakişi, Ege Üniversitesi Fen Fakültesi, Biyoloji Bölümü Zooloji Anabilim Dalı, İzmir, Türkiye Phone: 0232-311 2262 E-mail: hatice.karakisi@ege.edu.tr doi:10.5152/tpd.2012.41 
laticeps, Dactylogyrus extensus, Ergasilus sieboldi, Gyrodactylus elegans, Posthodiplostomum cuticola, Argulus foliaceus, Dactylogyrus phoxini, Glochidium sp., Diplostomum sp., Ligula intestinalis.

The aim of this study was identification of the parasites of the common carp from Tahtalı Dam Lake.

\section{METHODS}

Tahtalı Dam Lake is $40 \mathrm{~km}$ south of Izmir. It provides the large part of İzmir drinking water.

The study was carried out from September 2007 to May 2008 in Tahtalı Dam Lake. During this study, 47 common carp were caught. The specimens were between 25.8 and $42.8 \mathrm{~cm}$ in length (mean $34.3 \mathrm{~cm}$ ) and between 242 and $862 \mathrm{~g}$ in weight (mean $493.2 \mathrm{~g}$ ). After capture, the fish were transported live to the laboratory. They were kept in aquaria. They were measured and weighed before examination. Afterwards, they were dissected as quickly as possible within a few days. The skin, fins and gills were investigated for ectoparasites. Then, the digestive tract and inner organs were examined for endoparasites. They were dissected out and placed in petri dishes containing a physiological solution. The dissection of organs were done by using stereomicroscope. The parasite specimens were fixed in hot $70 \%$ ethyl alcohol or Bouin's fluid. The nematode and crustacean specimens were covered with glycerine-gelatine. The taxonomical determination were done according to Bykhovskaya-Pavlovskaya (8), Markevich (9), Moravec (10).

\section{RESULTS}

We investigated 47 common carp in the Tahtalı Dam Lake and found 3 parasite species. Gills were infected with Dactylogyrus extensus, the intestine was infected with Contracaecum sp. larvae and skin and fins were infected with Lernaea cyprinacea.

In our study, Dactylogyrus extensus (Figure 1,2) were the dominant taxon. This parasite species was recorded on the common carp throughout the year except for December 2007 and January 2008. Dactylogyrus extensus infection was the highest (75\%) in May, and the lowest (50\%) in October and November

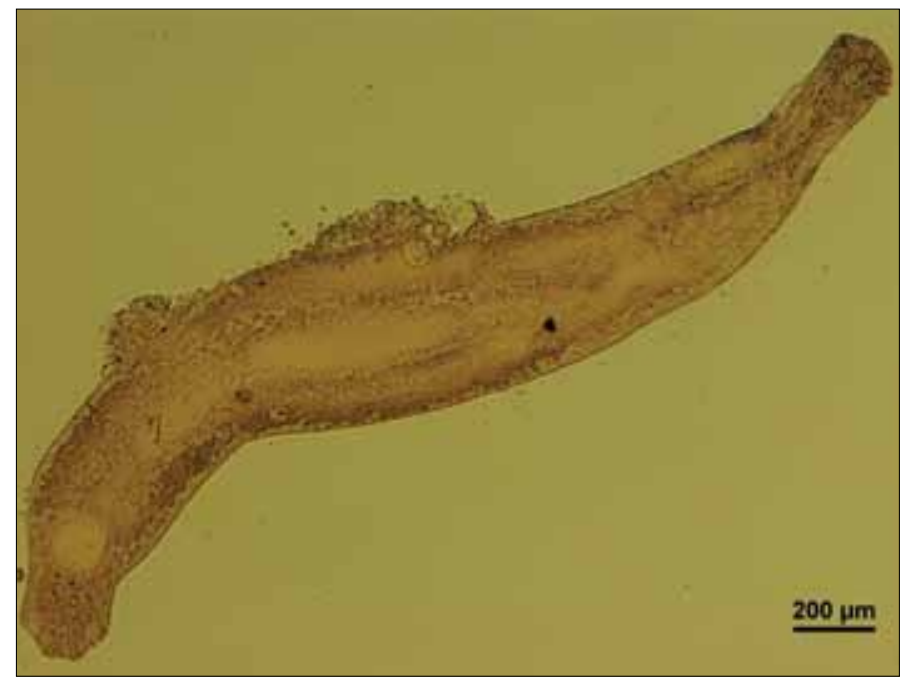

Figure 1. Dactylogyrus extensus general view
2007. A total of 26 of 47 (55.3\%) fish were infected with D. extensus (Table 1).

The second dominant species was Contracaecum sp. larvae (Figure 3,4). This species was recorded on the common carp in September, October, March and April; maximum intensity of infection was observed in March. 8 of 47 fish were infected by Contracaecum sp. larvae.

Lernaea cyprinacea (Figure 5, 6) was recorded on the common carp only in October, February and May. L. cyprinacea infection was highest in May.

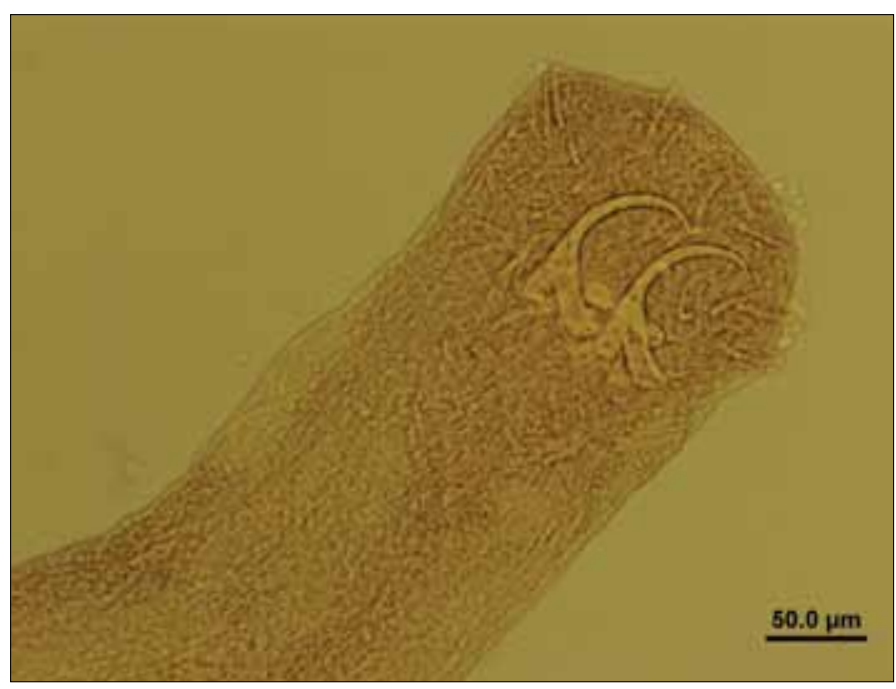

Figure 2. D. extensus haptor

Table 1. The infection rates of the parasites of common carp from Tahtalı Dam Lake.

\begin{tabular}{|c|c|c|c|c|c|c|c|}
\hline & \multirow[b]{2}{*}{ 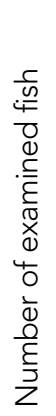 } & \multicolumn{6}{|c|}{ Parasite Species } \\
\hline & & 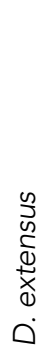 & 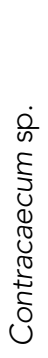 & 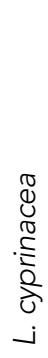 & 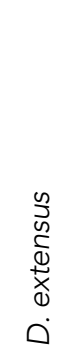 & 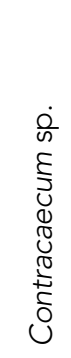 & 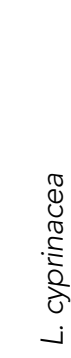 \\
\hline Months & & \multicolumn{3}{|c|}{$\begin{array}{l}\text { Number of } \\
\text { Infected Fish }\end{array}$} & \multicolumn{3}{|c|}{$\begin{array}{c}\text { Infection Rate } \\
\text { (\%) }\end{array}$} \\
\hline September & 10 & 6 & 2 & 0 & 60.0 & 20.0 & 0 \\
\hline October & 6 & 3 & 1 & 1 & 50.0 & 16.6 & 16.6 \\
\hline November & 4 & 2 & 0 & 0 & 50.0 & 0 & 0 \\
\hline December & 2 & 0 & 0 & 0 & 0 & 0 & 0 \\
\hline January & 2 & 0 & 0 & 0 & 0 & 0 & 0 \\
\hline February & 5 & 3 & 0 & 1 & 60.0 & 0 & 20.0 \\
\hline March & 7 & 4 & 3 & 0 & 57.1 & 42.8 & 0 \\
\hline April & 7 & 5 & 2 & 0 & 71.4 & 28.6 & 0 \\
\hline May & 4 & 3 & 0 & 1 & 75.0 & 0 & 25.0 \\
\hline Total & 47 & 26 & 8 & 3 & 55.3 & 17.0 & 6.4 \\
\hline
\end{tabular}




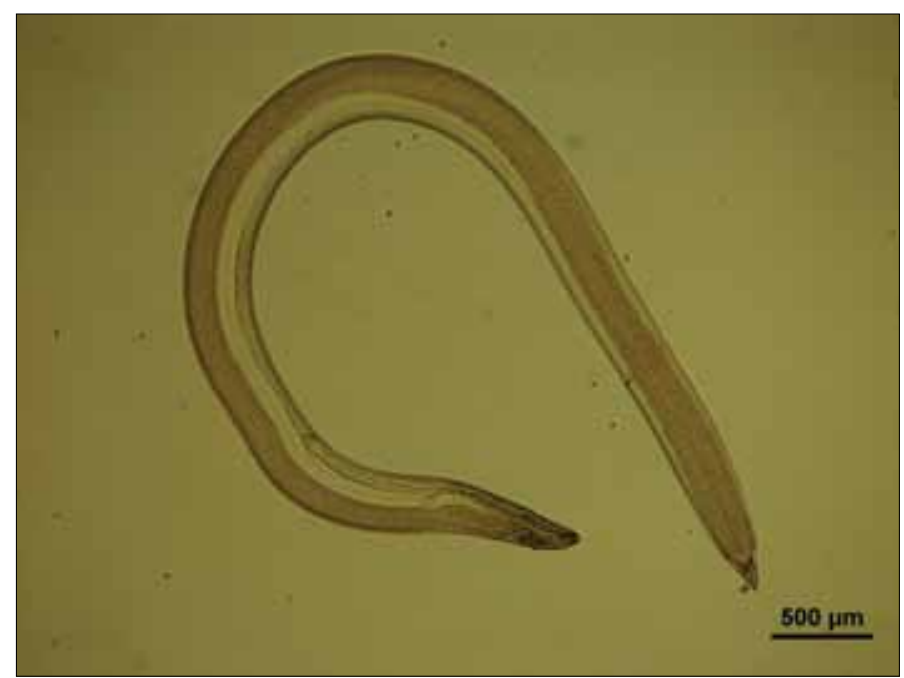

Figure 3. Contracaecum sp. larvae

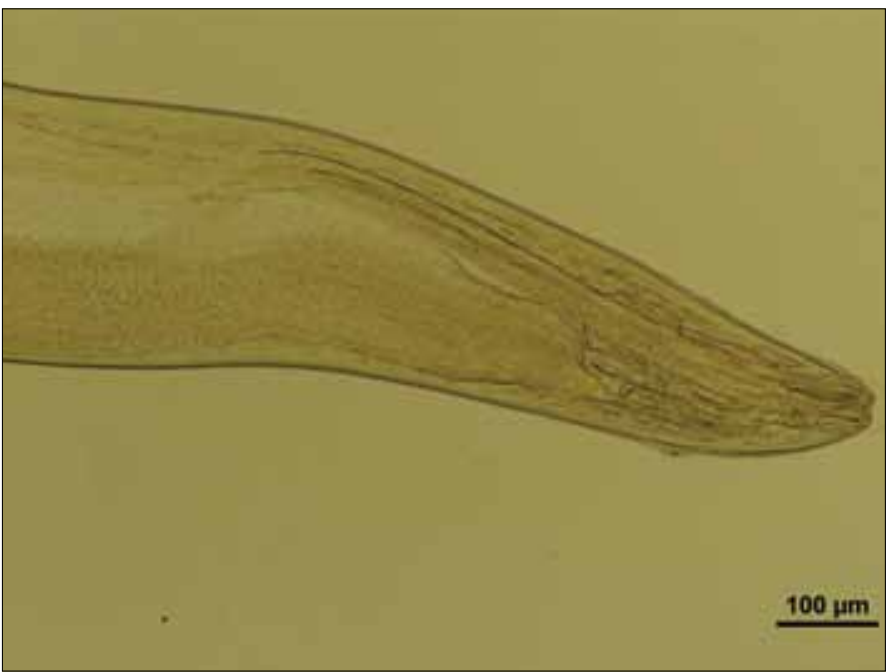

Figure 4. Contracaecum sp. larvae anterior

\section{DISCUSSION}

In this study 3 parasite species were identified on the common carp: Dactylogyrus extensus (Monogenea), Contracaecum sp. larvae (Nematoda) and Lernaea cyprinacea (Crustacea).

There are many research studies on the parasites of the common carp in Turkey. Dactylogyrus minutus was recorded on the gills of common carp, Bothriocephalus acheilognathiand Caryophyllaeus laticeps in the intestine of host fish from Kovada Lake (6). Dactylogyrus extensus and Ergasilus sieboldi were determined on the gills, C. laticeps in the intestine of common carp from Dalyan Lagoon (2). In another study, Gyrodactylus elegans, Dactylogyrus extensus, Posthodiplostomum cuticola, B. acheilognathi and Argulus foliaceus were found from Eber Lake (4). Dactylogyrus extensus, D. phoxini, Gyrodactylus sp. and Glochidium sp. were recorded on the gills, C. laticeps and $B$. acheilognathi in the intestine, Diplostomum sp. was found in the eye lens of host fish from Sapanca Lake (5).

The tudy results show that the major parasite is Dactylogyrus extensus. D. extensus was also recorded from all other region of

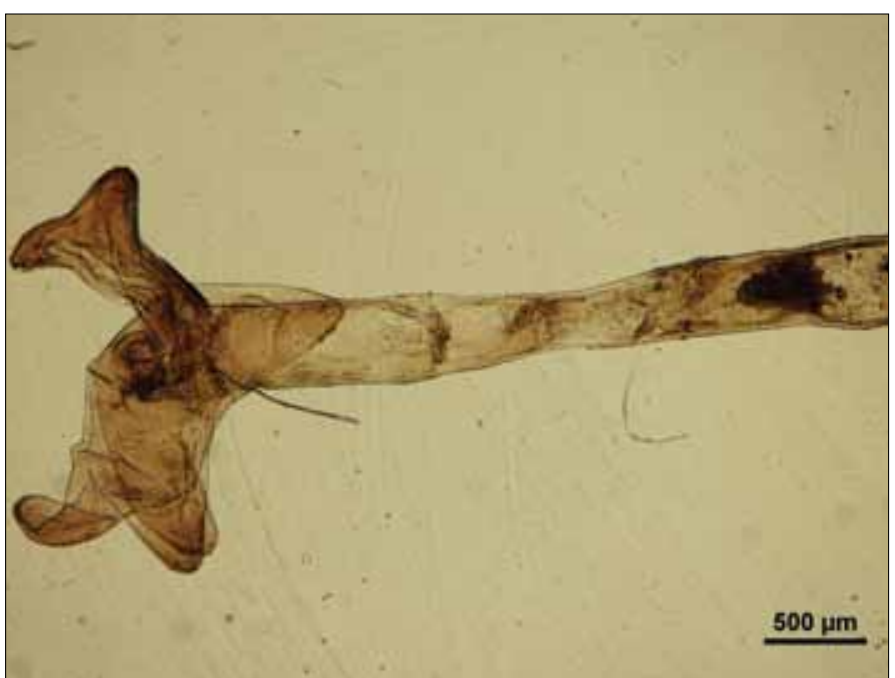

Figure 5. Lernaea cyprinacea

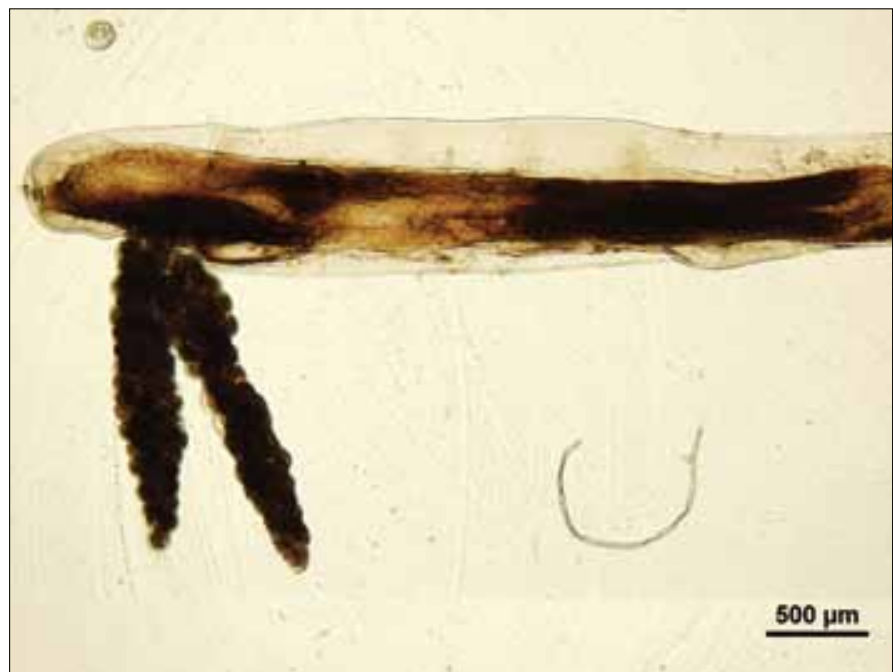

Figure 6. L. cyprinacea gonad

Turkey (such as Akşehir Lake, Dalyan Lagoon, Eber Lake, İznik Lake, Karamık Lake, Sapanca Lake, Selevir Dam Lake) (2, 4, 5, 11-14).

Contracaecum sp. larvae has been detected in Vimba vimba from Gölbaşı Dam Lake (15), in Carassius carassius from Kovada Lake (16), in Rutilus rutilus and Scardinius erythrophthalmus from Kocadere Stream (17), in Carassius carassius from Uluabat Lake (18), in Barbus plebejus escherichi from Doğancı Dam Lake (19). Although Contracaecum sp. larvae was reported from various freshwater fishes, up to now there has been no report on Cyprinus carpio in Turkey.

Lernaea cyprinacea in some cases brings about serious losses to the fish, and sometimes leads to death. Khalifa and Post (20), reported that Lernaea cyprinacea leads to death especially when it settles on the gills.

Lernaea cyprinacea was found in some of the aquarium fish (Poecilidae) in the Mersin district by Koyuncu et al. (21). They recorded that the Lernaea cyprinacea was responsible for the death of the fish. 
In this study, metazoan parasites of the common carp from Tahtalı Dam Lake were determined. This parasite species were new records for Tahtalı Dam Lake.

\section{Conflict of Interest}

No conflict of interest was declared by the authors.

\section{REFERENCES}

1. Geldiay R, Balık S. Türkiye Tatlısu Balıkları. Ege Üniversitesi Su Ürünleri Fakültesi Yayınları. İzmir 2007.

2. Aydoğdu A, Öztürk MO, Oğuz MC, Altunel FN. Investigations on metazoan parasites of common carp (Cyprinus carpio L. 1758) in Dalyan Lagoon, Karacabey, Turkey. Acta Veterinaria-Beograd 2001; 51: 351-8.

3. Kır I, Ayvaz Y, Barlas M, Özan-Tekin S. Karacaören I Baraj Gölü'nde yaşayan sazan (Cyprinus carpio L., 1758)'lardaki parazitlerin mevsimsel dağılımları ve etkileri. Turkiye Parazitol Derg 2004; 28: 45-9.

4. Öztürk MO. [An investigation of metazoan parasites of common Carp (Cyprinus carpio L.) in Lake Eber, Afyon, Turkey.]. Turkiye Parazitol Derg 2005; 29: 204-10.

5. Uzunay E, Soylu E. [Metazoan parasites of carp (Cyprinus carpio Linnaeus, 1758) and vimba (Vimba vimba Linnaeus, 1758) in the Sapanca lake]. Turkiye Parazitol Derg 2006; 30: 141-50.

6. Kir I, Ozan ST. Helminth infections in common carp, Cyprinus carpio L., 1758 (Cyprinidae) from Kovada Lake (Turkey). Turkiye Parazitol Derg 2007; 31: 232-6.

7. Tekin-Özan S, Kır I, Barlas M. Helminth parasites of common carp (Cyprinus carpio L., 1758) in Beyşehir Lake and population dynamics related to month and host size. Turkish Journal of Fisheries and Aquatic Sciences 2008; 8: 201-5.

8. Bykhovskaya-Pavlovskaya IE, Gusev AV, Dubinina MN, Izyumova NA, Smirnova TS, Sokolovskaya IL, et al. Key to Parasites of Freshwater Fish of the U.S.S.R., (Çev. A. Birron and Z. S. Cole). Israel Program for Scientific Translations Jerusalem 1964. p. 919.

9. Markevich AP. Parasitic Fauna of Freshwater Fish of the Ukrainian S.S.R. Oldbourne Press 121, Fleet Street, London 1951. p. 388.

10. Moravec F. Parasitic Nematodes of Freshwater Fishes of Europe. Kluwer Academic Publishers Dordrecht/ Boston/ London 1994. p. 473.
11. Kartal K, Oztürk MO. [Investigations of ectoparasite fauna of some fish species (Cyprinus carpio Linnaeus, 1758; Cobitis simplicispinna Hanko, 1924) from Lake Akşehir (Konya)]. Turkiye Parazitol Derg 2009; 33: 101-6.

12. Aydoğdu A, Altunel FN. Helminth parasites (Plathelminthes) of common carp (Cyprinus carpio L.) in Iznik Lake. Bull. Eur. Ass. Fish Pathol 2002; 22: 343-8.

13. Kutlu HL, Öztürk MO. Karamık Gölü (Afyonkarahisar)'deki Cyprinus carpio Linnaeus, 1758 (Sazan)'nun metazoon parazitleri üzerinde anatomik, morfolojik ve ekolojik bir araştırma. E.Ü. Su Ürünleri Dergisi 2006; 23: 389-93.

14. Öztürk MO, Bulut S. Selevir Baraj Gölü (Afyonkarahisar)'ndeki Cyprinus carpio L. (Sazan)'nun metazoon parazit faunası üzerine bir araştırma. Fırat Üniv Fen ve Müh Bil Der 2006; 18: 143-9.

15. Aydoğdu A, Emence $H$, Innal D. [The occurrence of helminth parasites in Vimba (Vimba vimba L. 1758) of Golbasi (Bursa) Dam Lake, Turkey]. Turkiye Parazitol Derg 2008; 32: 86-90.

16. Tekın-Özan S, Kir I. [An investigation of parasites of goldfish (Carassius carassius L., 1758) in Kovada Lake.]. Turkiye Parazitol Derg 2005; 29: 202-3.

17. Selver MM. Kocadere Deresi'nden yakalanan bazı balık türlerindeki helmint faunası. Bursa: Uludağ Üniversitesi Sağlık Bilimleri Enstitüsü Doktora Tezi. 2008.

18. Emence H. Uluabat (Apolyont) Gölü havuz balıkları (Carassius carassius L., 1758)'nın helmintholojik yönden araştıııması. Bursa: Uludağ Üniversitesi Fen Bilimleri Enstitüsü Yüksek Lisans Tezi. 2004.

19. Aydoğdu A, Altunel FN, Yıldırımhan HS. The occurrence of helminth parasites in barbel (Barbus plebejus escherichi, Steindachner, 1897) of the Doğancı (Bursa) Dam Lake, Turkey. Acta Veterinaria-Beograd 2002; 52: 369-80. [CrossRef]

20. Khalifa AK, Post G. Histopathological effect of Lernaea cyprinacea (a copepod parasite) on fish. Progressive Fish-Culturist 1976; 38: 110-3. [CrossRef]

21. Koyuncu CE, Dönmez AE. Mersin bölgesinde yetiştiriciliği yapılan bazı akvaryum balıkları (Poecilidae)'nda rastlanılan Lernaea cyprinacea (Linnaeus, 1758) enfeksiyonu. E.Ü. Su Ürünleri Dergisi 2006; 23 : 265-7. 